The International Journal Of Engineering And Science (IJES)

|| Volume || 6 || Issue || 3 || Pages || PP 129-136 || 2017 ||

ISSN (e): $2319-1813 \operatorname{ISSN}$ (p): $2319-1805$

\title{
Analysis of Economic Growth Quality to Improve Society Welfare in Southeast Sulawesi
}

\author{
Muh. Nur ${ }^{1}$, LM. Harafah ${ }^{2}$, Gamsir $^{3}$, Abd. Azis Muthalib ${ }^{4}$, Nasrul Anaam ${ }^{5}$, \\ Zainuddin Sainong ${ }^{6}$ \\ 1,2,3,4,6 Graduate School, Doctoral Program in Economics Halu Oleo University \\ ${ }^{5}$ Institute of Economic Science (STIE 66) Kendari Southeast Sulawesi, Indonesia
}

\begin{abstract}
This study entitled "Analysis of Economic Growth Quality to Improve Society Welfare in Southeast Sulawesi". The research activities carried out as an effort to help the government of Southeast Sulawesi in solving economic problems is based on the economic growth achieved over the value of the national average but has not been able to provide overall welfare for the people. The aims to be achieved in this research is to investigate and analyze the impact economic growth quality to improve society welfare in Southeast Sulawesi. The research was conducted by taking samples at six districts and two cities in Southeast Sulawesi. The data used is quantitative data that is processed by the research model that had been developed by using statistical analysis econometric approach with panel data regression.The results showed that economic growth quality have significant impact with a positive direction to rate of society welfare in several districts / cities in Southeast Sulawesi. This means that economic growth quality that proxy with the pace of GDP growth, Gini Ratio Index, Williamson Index, the percentage decline in poverty and unemployment were able to improve society welfare in some districts / cities in Southeast Sulawesi which proxy with income per capita and Human Development Index during the period from 2006 until 2015.
\end{abstract}

Keywords: Economic growth quality and Society welfare.

Date of Submission: 02 March $2017 \longrightarrow$ Date of Accepted: 20 March 2017

\section{INTRODUCTION}

Development basically aims to improve the lives and society welfare. Welfare reforms realized from various human endeavors choose the settlement of various issues his own life (problem of choise) without interference by other parties (government) but rests entirely on the settings of the market mechanism by the hands of the subtle (insinvisible hand) Adam Smith (Mankiw N . Gregor: 2001). But along with the development activities in all fields, humans are faced with fierce competition so that the need for government intervention to regulate the balance of the overall economy (aggregate) to reach the level of prosperity. J.M. Keynes inside (Mankiw N. Gregor: 2008). Government involvement with any form of control policies should have been able to improve the lives and well-being. However this can not be denied that there are still some people living in poverty and powerlessness as a result of the failure of the implementation of economic development has not been done properly, fairly and equitably. Todaro (2003), suggests that the public welfare may be perceived at the level of community life marked by terentaskannya of poverty, better health, the acquisition of a higher education level, and productivity levels of society.

Nevertheless, the basic phenomenon occurring during this time it appears that, at first carried out the construction sector in developing countries or emerging regions such as Southeast Sulawesi focuses on efforts to achieve economic growth at constant prices in 2010 amounted to 9.01 percent of 2010 to 2014 above the national average value. But the high economic growth led to unequal distribution of income as measured by the Gini Ratio Index of 0.41 is still in the category fairly evenly along terjadiya development gaps between regions autonomous districts / cities in Southeast Sulawesi and is unable to provide the level of overall well-being for citizens in general that is visible from the acquisition value of the Human Development Index (HDI) with an average value of 71.18 still only ranks 25 th among the 33 provinces in Indonesia (BPS Prov. Sultra 2015).

Therefore, efforts must be made to improve society welfare by reducing the development gaps, the efficiency of economic activity, in order to strengthen the stability and solidarity of social justice in economic development can be achieved (Todaro, 2003). In addition, the government should formulate development policy implications in every area is done so that the inequality of development among regions can be more evenly distributed implementation (Sjafrizal, 2008). In order for the process of economic development should becarried out continuously in an effort to improve the welfare of society as a fair and equitable in order to accomplish the level of society welfare can be realized with the Human Development Index ratings optimal. This assessment is 
in line with the method of measuring the level of welfare is done by (Cooke Martin, et al., 2007) which uses Human Development Index to see society welfare. Based on these circumstances indicate the need for studies in a systematic and in-depth about how to create a quality economic growth to improve prosperity in Southeast Sulawesi. This is in line with the results of research Marinela G. (2012), Kuznetsova V, Natalia and Vorobeva A, Natalia (2015), which concluded that economic development can be investigated from various major factors by analyzing various economic development indicators complex. In connection with this, it is considered important to conduct an analysis of the "Analysis of economic growth quality to improve society welfare in Southeast Sulawesi".

\section{LITERATURE REVIEW}

Economic development goals to be achieved is economic growth. Economic growth is the increase in output per capita, resulting in increased overall welfare of society. Willam H. Branson, J.M (1981) Economic growth occurs when a period long enough output per capita has a tendency to increase, although it may be in any given year per capita output declined.(Boediono 1999:1).

Keynes asserted theory of economic growth on the demand side, namely the effective demand determines the equilibrium level and national income. (Mankiw, 2001). Based (UNDP Report, 2006) stated that the quality of economic growth can be realized if economic development can provide a high economic growth and tends to increase from year to year. According to Prasetyo Eko (2008), economic growth, quality is growth that creates equal distribution of income, poverty and open up vast employment opportunities, improvement of high economic growth accompanied by the distribution of income is evenly distributed so as to equalize the results of economic development at all fair territory and able to reduce the poverty level of the population. So that the individual welfare of society and be able to demonstrate achievement of success (Mlachila Monfort et al. 2014). According to Eko Prasetyo (2008) stated that the quality of economic growth by taking into account income distribution and poverty alleviation and unemployment. This is in line with the basic concepts of the theory written by the United Nations Development Programme (UNDP, 2006), that to see the quality of the economic growth of a country or region can be assessed by several indicators of Simon Kuznets, (1955), World Bank (2007) , World Bank (2004), Sudantoko H. Djoko, (2009), Sukirno, (2013), among others: the growth in GDP / GRDP, income distribution, inequality between regions, poverty reduction and employment expansion.

Social welfare is defined by the United Nations (1950) is as a prosperous state or condition full, physical, mental and social and not just certain social evils only.In accordance with Act 6 of 1974 on the basic provisions of social welfare.

Gross National Product (GNP) compared to the total population in a given time period as a reflection of a country's level of social welfare (Sukirno, 2013). According to Hasbullah Jousairi (2012) mention that the Human Development Index (HDI) is an important indicator to measure success in the effort to build the quality of human life / community / population. HDI itself explain the population's ability to enjoy the income, health and education. (UNDP, 2004).

According to Sudantoko H. Djoko (2009) states that the normative ideal development process is a step that can create improvements fortune and prosperity for the people. Development as a process of actually needed at any time and without the perspective of the place where he was executed. So initially the construction carried out in developing countries focused on efforts to increase economic growth and per capita income in the maximum levels.

\section{RESEARCH METHODS}

This study is based on the theoretical basis associated with the phenomenon that became the focus of the study, the research compiled a chart like that can be presented in a scheme shown in figure 3.1 below:

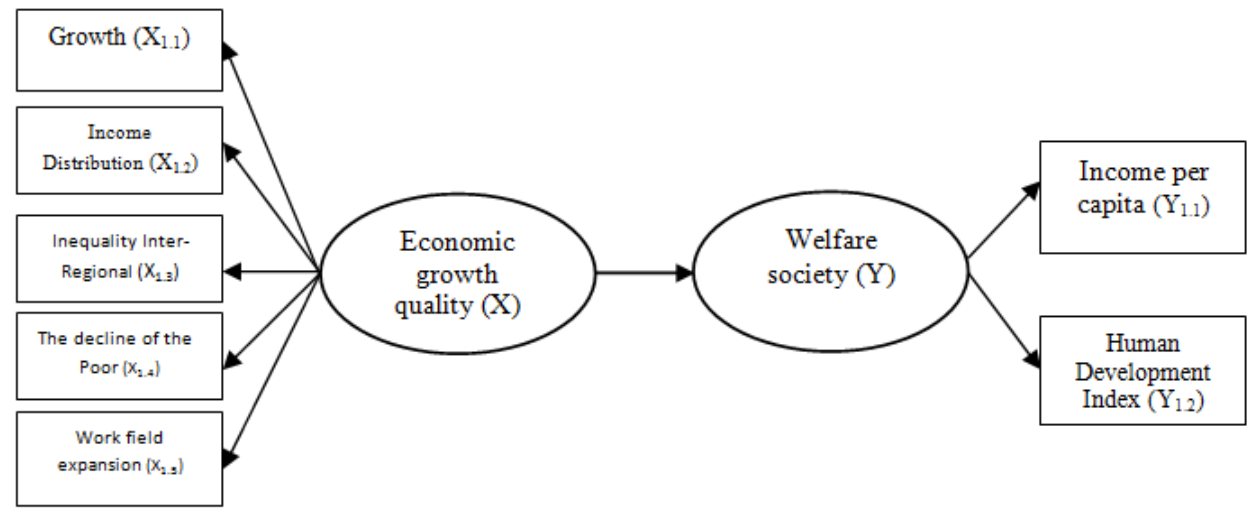


This research was conducted in the area of Southeast Sulawesi province were carried out to help local governments develop models of economic development so that welfare society can be achieved in accordance with the government's goals and objectives that have been set. This study was conducted at six districts and two cities alone. Districts in question is Buton, Muna, Konawe, Kolaka, North Kolaka and South Konawe, while the other two cities, Kendari and Bau-Bau. Sources and types of data used in this research is secondary data taken at each regency / city in Southeast Sulawesi. The data used in this research is quantitative data.

For the effective achievement of the goals of research that is descriptive quantitative, then the data analysis quality of economic growth as measured using data GRDP based on constant prices, data from the calculation of Gini Ratio Index, computed values Williamson Index, percentage of poor people and the unemployment rate open district / city in Southeast Sulawesi Province. To determine the level of welfare of the people in Southeast Sulawesi province in each district / city used the data of income per capita and the value of Human Development Index respective districts / cities in Southeast Sulawesi. The equation of multiple regression models are used as defined by McClave, Benson and Sincich (2005: 768), Agus Widarjono (2013: 356), which uses linear regression panel data methods Pooled Least Squares as follows:

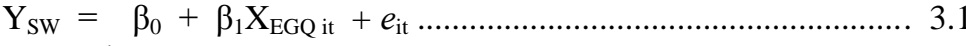

$$
\begin{aligned}
& \text { Where: } \\
& \mathbf{Y}_{\mathrm{SW}} \quad=\text { Improving Society Welfare } \\
& \beta_{0} \quad=\text { The constant coefficients } \\
& \beta_{1} \mathrm{X}_{\mathrm{EGQ}}=\text { Economic growth quality } \\
& e_{\text {it }} \quad=\text { Residual value }
\end{aligned}
$$

\subsection{Economic growth quality}

\section{RESULTS AND DISCUSSIONS}

The economic growth quality can be realized if economic development can provide a high economic growth and tends to increase from year to year. Increased economic growth should be able to encourage the creation of economic development in all fields. So to see the economic growth quality in Southeast Sulawesi, need to be examined thoroughly for the changes increased growth of GDP in each district / city in Southeast Sulawesi with the indicators of measurement. Among them are changes in the rate of increase in GDP growth to changes in the distribution of income distribution indicators Gini Ratio Index, changes in the rate of increase in GDP growth to changes in inequality of development among regions with Williamson index and changes in the rate of increase in GDP growth to changes in the percentage reduction of the poor as well as changes in the rate of increase in GDP growth to change the number of unemployed in each district / city in Southeast Sulawesi during the period 2006 to 2015 . the economic growth quality that is formed through a process of increasing the economic growth of the indicators of measurement are described as follows:

\subsection{The rate of economic growth on changes in income distribution}

This condition can be measured by comparing the growth rate of the GDP by the Gini RatioIndex as a measure of inequality of income distribution. Gini Ratio Index ranges between zero and one. When the Gini Ratio is equal to zero means that the income distribution is very uneven because each segment of the population receive the same share of revenues. The general state of economic growth with equitable distribution of income distribution in Southeast Sulawesi province can be seen in the following figure:

Graph 4.1 Average growth in the GDP and the Gini ratio index of the respective districts / cities in Southeast Sulawesi Province Period Year 2006-2015.

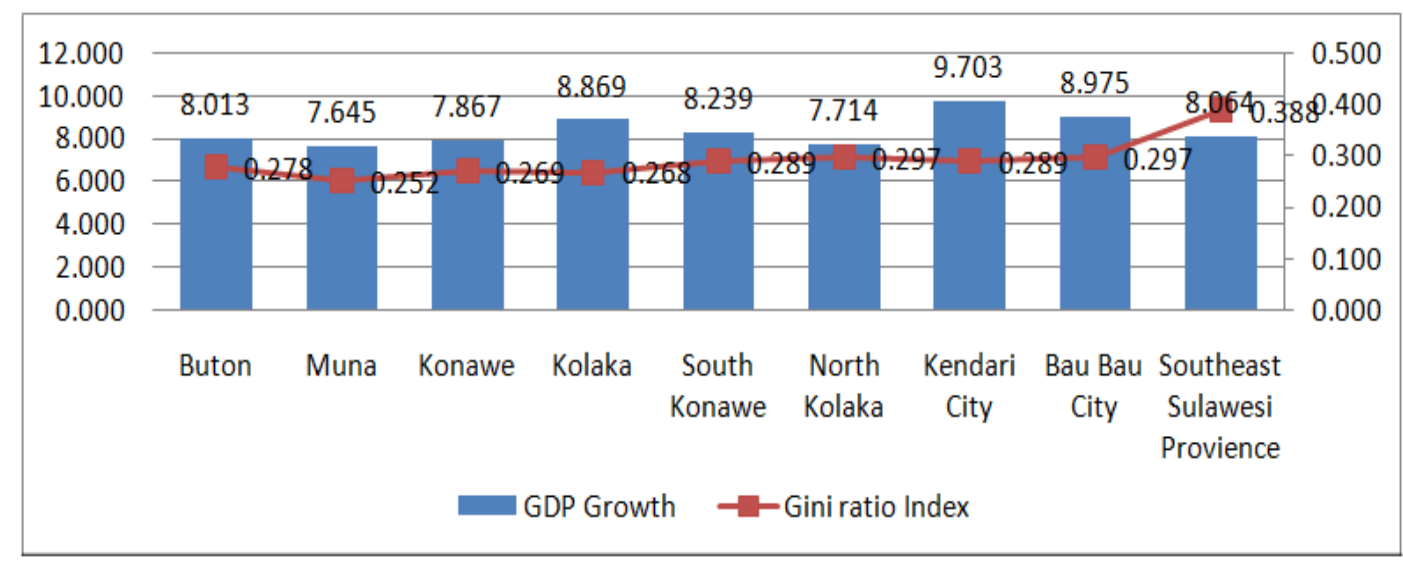

Source: BPS several publications (processed). 
Based on the graph above 4.1 indicate that GDP growth in comparison with the Gini Ratio Index of multiple districts / cities in the Southeast province the number continues to increase from year to year but the growth rate fluctuates. Similarly, the Gini Ratio Index tends to fluctuate. Average GDP growth in Southeast Sulawesi province from 2006 to 2015 amounted to $8.06 \%$ with a Gini Ratio Index of 0.388 .

\subsection{The rate of economic growth on changes in inequality inter-regional development}

The development process is done through efforts to increase the rate of GDP growth is not automatic can reduce inequality region, but it could lead to higher inequality, if not carried out with good development policy. Measuring inequality of development among regions in Southeast Sulawesi province were caused by the growth of the GDP used methods Williamson Index. Williamson Index value close to 1 means very lame and if its value is close to zero means very evenly shown in the graph as follows:

Graph 4.2 Average growth of the GDP by Williamson Index respective districts / cities in Southeast Sulawesi Province Period Year 2006-2015.

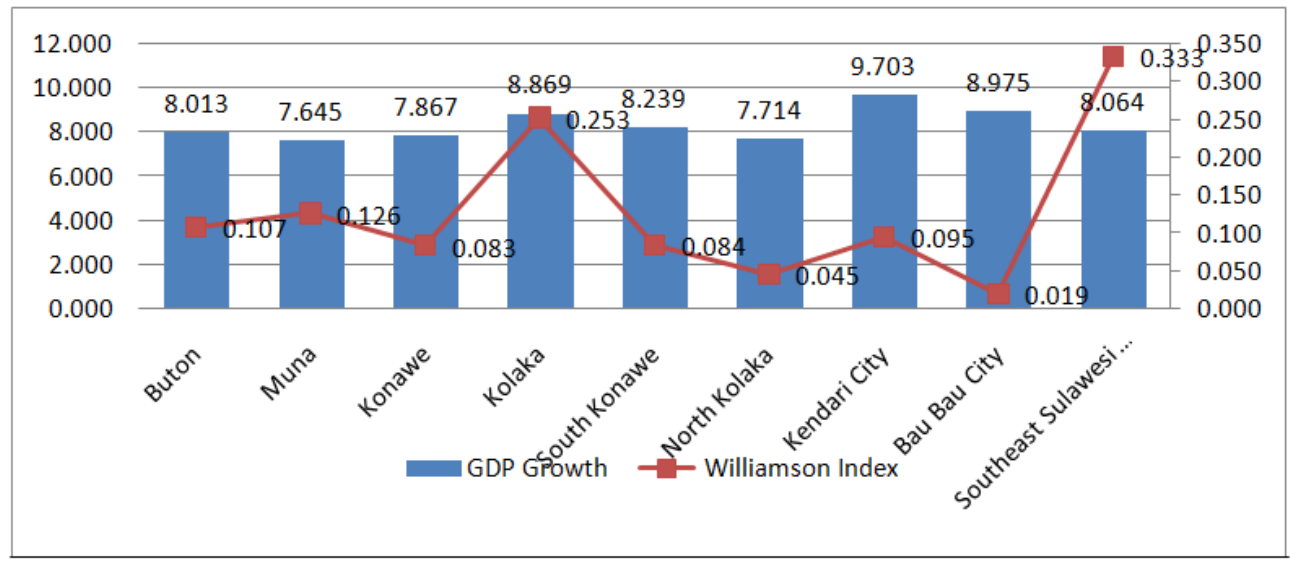

Source: BPS several publications (processed).

4.2 based graphic image above shows the average ratio of the GDP growth Williamson Index several districts / cities in the Southeast Sulawesi province whose numbers continued to increase from year to year but the growth rate fluctuates. Similarly, the index value Williamson who tend to fluctuate and vary depending on each district / city. Average GDP growth in Southeast Sulawesi province from 2006 to 2015 amounted to 8.06\% with Williamson Index of 0.33 .

\subsection{The of economic growth on decline in poverty}

Poverty is one of the problems in the process of economic development. Almost every region experiencing poverty problems, both regions developed and emerging regions. It's because of the confidence of policy makers and planners will be the trickle down effect to people's lives. Economic growth is expected to provide benefits for all people, especially the poor. The rate of economic growth of a region can lead to changes in poverty as is the case in several districts / cities in Southeast Sulawesi Province. It can be seen in the graph as follows:

Chart 4.3 Average Percentage Growth of the GDP by the poor population of each district / city in Southeast Sulawesi Province Period Year 2006-2015.

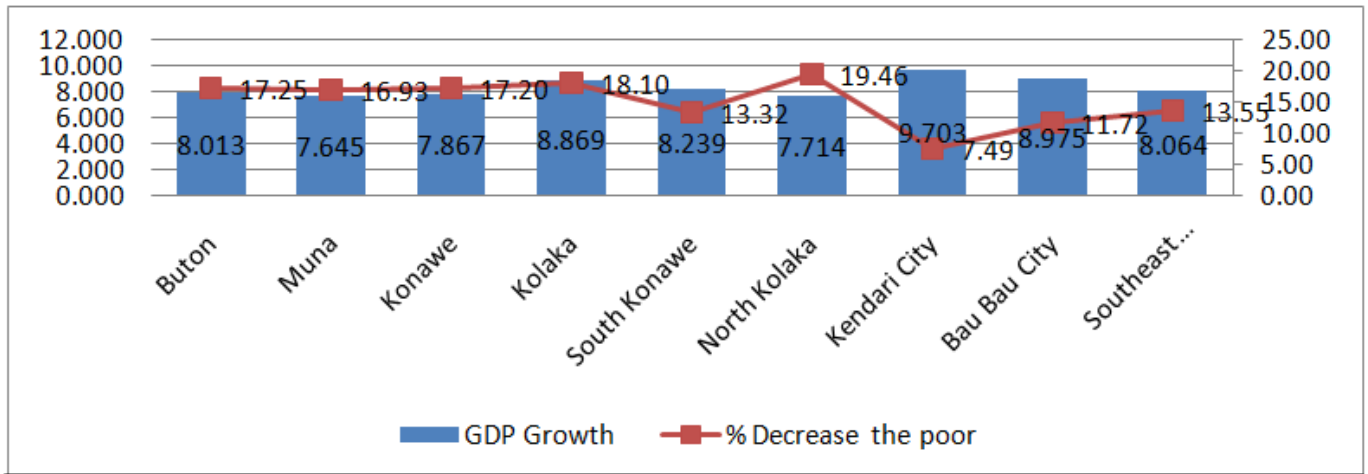

Source: BPS several publications (processed). 
4.3 Based on chart image above shows a comparison of the average GDP growth in the percentage of poor people some districts / cities in the Southeast province is steadily declining from year to year. Similarly, the average percentage of poverty vary in each district / city. Average GDP growth in Southeast Sulawesi province from 2006 to 2015 amounted to $8.06 \%$ with the percentage of poverty average of $13.55 \%$.

\subsection{Economic growth on changes in unemployment rate}

Employment opportunities are a source of income for workers to earn incomes that can improve prosperity. The linkage between economic growth and unemployment is very strong. Along with economic growth, the unemployment rate tends to decrease the area shown in the increase of new labor force that can be absorbed by the jobs available. As was the case in Southeast Sulawesi indicates that GDP growth causes changes in the expansion of the labor force so that the open unemployment rate could decline. The average economic growth rate of open unemployment respective districts / cities in Southeast Sulawesi can be seen in the image graph as follows:

Chart 4.4 The average growth of the GDP with the Unemployment Rate respective districts / cities in Southeast Sulawesi Province Period Year 2006-2015.

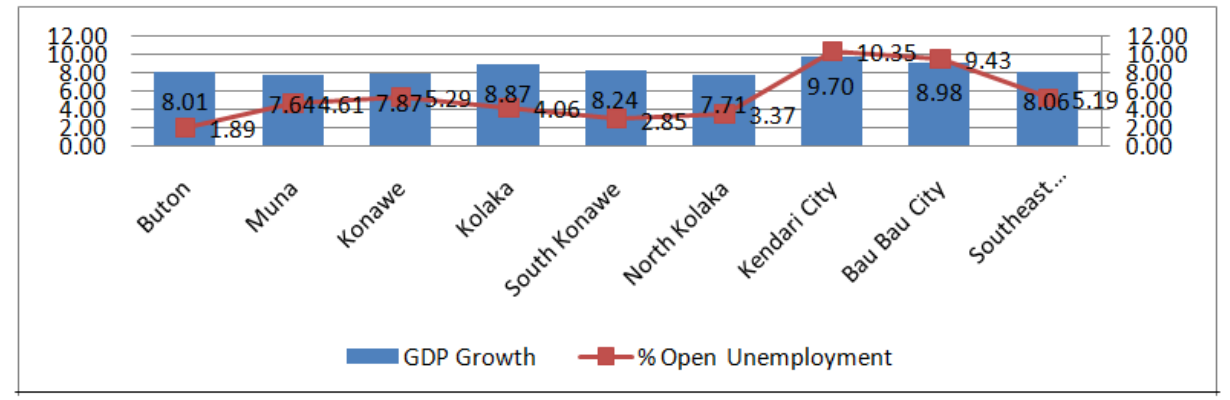

Source: BPS several publications (processed).

4.4 based graphic image above shows the comparison of the average GDP growth in the unemployment rate open several districts / cities in the Southeast province and tended to fluctuate from year to year. Similarly, the average number of open unemployment differs in each district / city. Average GDP growth in Southeast Sulawesi province from 2006 to 2015 amounted to $8.06 \%$ with the number of unemployed an average of $5.19 \%$.

\subsection{The level of Society Welfare}

The level of welfare is a rational process towards the public release of the barriers to progress. So that social welfare can be obtained if the level of life, the fulfillment of basic needs, quality of life and human development can be achieved. To determine the level of welfare of a region required a measurement indicator is per capita public revenue and acquisition Human Development Index which will be described as follows:

GDP per capita; is a measure of a local people's income individuals who take into account the GDP of a region divided by the number of residents per mid-year. The measurement results in this study reflects the welfare of the people of Southeast Sulawesi province. GDP per capita in Southeast Sulawesi province shows the level of economic activity achieved in any given year. While economic growth showed no change in economic activity that occurred from year to year. Changes in the value of GDP per capita in Southeast Sulawesi province occurred from 2006 to 2015 is caused by two factors: changes in the level of real economic activity and price changes.The influence of these two factors caused by the GDP per capita of the votes according to constant prices during the year. In other words, development occurs on the number of physical goods and services produced in the economy of Southeast Sulawesi province grew from 2006 to 2015. For more details can be seen in the graph as follows:

Chart 4.5 GDP per capita based on constant price of each district / city in Southeast Sulawesi Province Period Year 2006-2015.

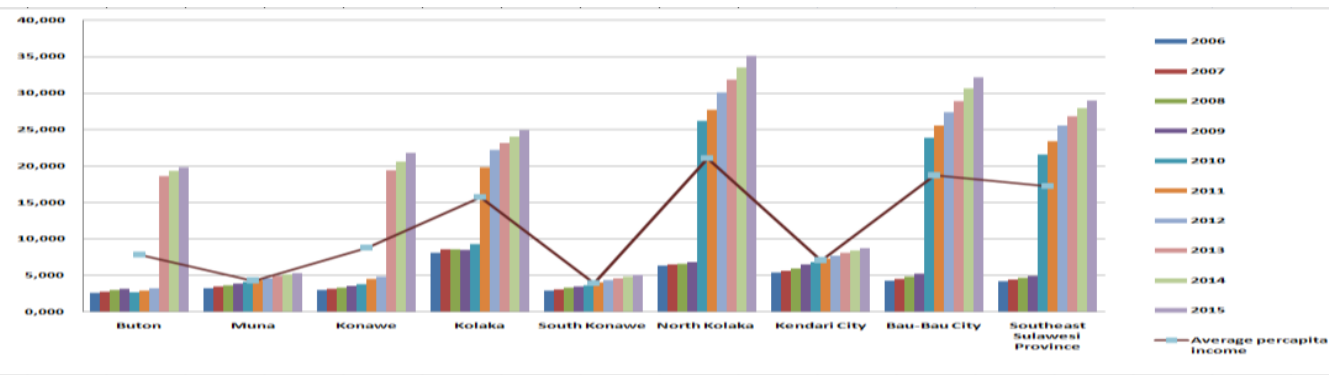

Source: BPS several publications (processed). 
Based on the graph 4.5 above shows the yield of GDP per capita several districts / cities in the Southeast province increased from year to year.Similarly, the average GDP per capita as per capita income of the people in each regency / city different. The average GDP per capita in Southeast Sulawesi province from 2006 to 2015 amounting to Rp. 17.22 million per year.

Human Development Index is the comparison measurement of life expectancy, literacy, education and standard of living of an area. Human Development Index is used to classify whether an area is already developed, developing or underdeveloped and also to measure the impact of economic policies on quality of life. So Human Development Index explain how residents can access development results in obtaining income, health, education, and so forth. Figures Human Development Index is a standard figure, so this figure can be compared with the same number of districts / cities in Southeast Sulawesi Province. Here's Human Development Index of each regency / city in Southeast Sulawesi in view of the economic security level based on indicators of Human Development Index among other areas indicated on the graph as follows:

Chart 4.6 Human Development Index value of each district / city in Southeast Sulawesi Province Period Year 2006-2015.

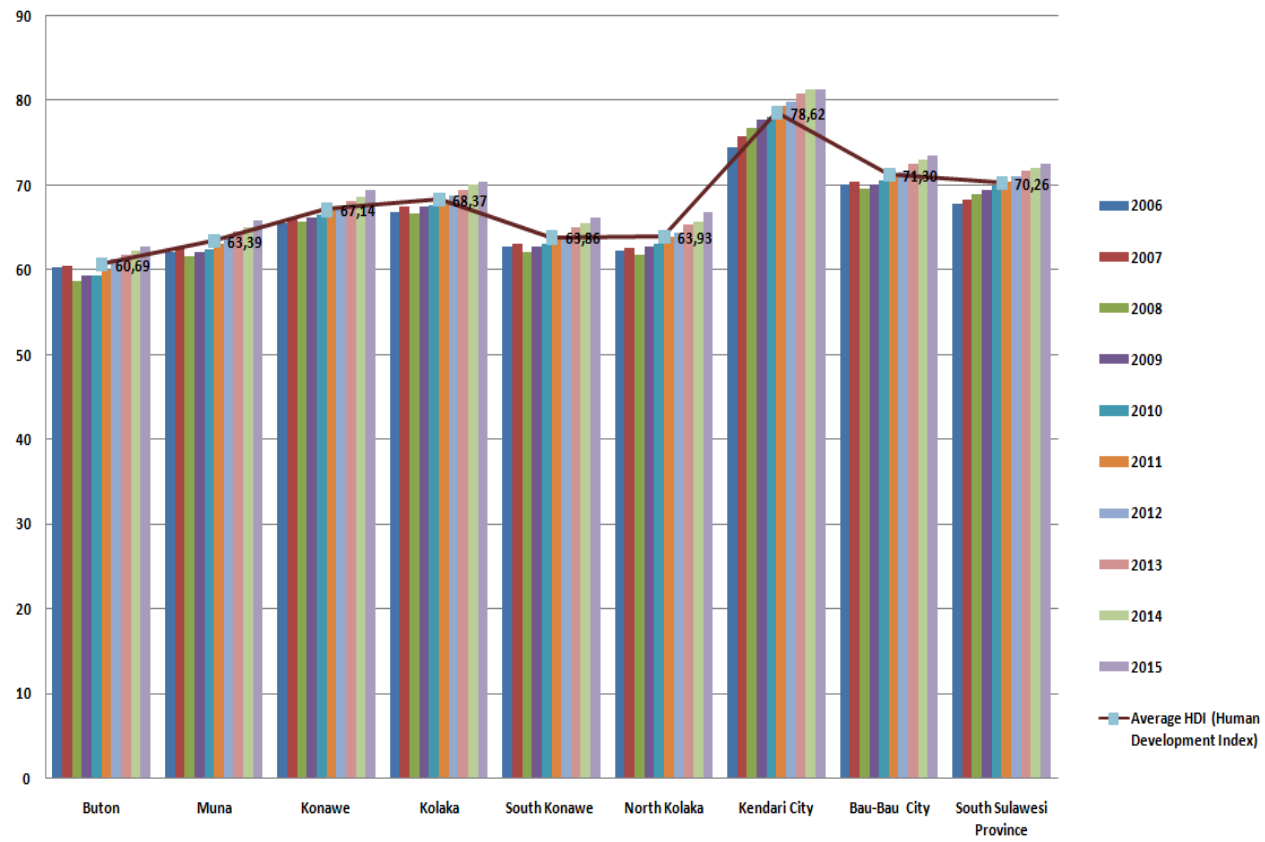

Source: BPS several publications (processed).

4.6 based graphic image above shows the yield of the Human Development Index (HDI) several districts / cities in the Southeast province increased from year to year.Similarly, the HDI value in each district / city different. The average GDP per capita in Southeast Sulawesi province from 2006 to 2015 amounted to 70.26.

Society of Southeast Sulawesi province has a level of prosperity that tends to increase as indicated by the increasing human development index from 2006 to 2015.The level of welfare of the province of Southeast Sulawesi seen from the average value of the index which is at $\leq 66$ criteria IPM $<80$ means that the status Human development community are in the upper middle category.

\subsection{The impact economic growth quality on welfare rate}

Based on the results of the regression analysis on panel data between the time series data from 2006 to 2015 and cross section data covering 8 districts / cities in Southeast Sulawesi.Using the data quality of economic growth with the GDP growth indicators, the Gini RatioIndex, Williamson Index, the percentage of poor and the percentage of open unemployment rate to the level of social welfare with the acquisition indicator GDP per capita and the value of the Human Development Index.In this study the methods used to estimate the model is the method of fixed effect. The result of the calculation of panel data regression with fixed effect model is shown as follows: 
Analysis of Economic Growth Quality to Improve Society Welfare in Southeast Sulawesi

Total panel (balanced) observations: 90

\begin{tabular}{|c|c|c|c|c|}
\hline Variable & Coefficient & Std. Error & t-Statistic & \\
\hline $\mathrm{C}$ & 88.81394 & 503.0593 & 0.176548 & 0.8603 \\
\hline \multirow[t]{2}{*}{ X_QEG } & 1.457538 & 0.135749 & 10.73703 & 0.0000 \\
\hline & \multicolumn{4}{|c|}{ Effects Specification } \\
\hline \multicolumn{5}{|c|}{ Cross-section fixed (dummy variables) } \\
\hline R-squared & 0.793575 & \multicolumn{2}{|c|}{ Mean dependent var } & 88.91111 \\
\hline Adjusted R-squared & 0.770352 & \multicolumn{2}{|c|}{ S.D. dependent var } & 9958.858 \\
\hline S.E. of regression & 4772.440 & \multicolumn{2}{|c|}{ Akaike info criterion } & 19.88354 \\
\hline Sum squared resid & $1.82 \mathrm{E}+09$ & \multicolumn{2}{|c|}{ Schwarz criterion } & 20.16130 \\
\hline Log likelihood & -884.7594 & \multicolumn{2}{|c|}{ Hannan-Quinn criter. } & 19.99555 \\
\hline F-statistic & 34.17226 & \multicolumn{2}{|c|}{ Durbin-Watson stat } & 1.630853 \\
\hline Prob(F-statistic) & 0.000000 & & & \\
\hline
\end{tabular}

The estimation results of panel data regression model Pooled Least Square was performed using a model fixed effect.Based on the results of model parameter estimation using panel data regression methods common effect, fixed effect and random effect and the results of the test data with the characteristics of the F test (Chow Test) and Hausman Test. The best model selected in this research is panel data regression model with fixed effect method. From the results of the calculation processing of the data, the panel data regression equation influence the quality of economic growth to the quality level of welfare in Southeast Sulawesi as follows:

$\mathrm{Y}_{\mathrm{SW}}=88.8164725091+1.41957902967 * \mathrm{X}_{\mathrm{EGQ}}+[\mathrm{CX}=\mathrm{F}]$

Based on these test results using Eviews program obtained significance value of $0.000<$ than the probability value 0.05 ; so it can be concluded that $\mathrm{Hi}$ is received. This means the quality of economic growth is positive and significant effect of 1.42 against the welfare of the people in several districts / cities in Southeast Sulawesi province in during the period from 2005 to 2015.This suggests that an increase in the quality of economic growth during the period from 2006 until 2015, is able to improve the general welfare of society in Southeast Sulawesi.In this study, the number of positive directional quality of economic growth to the level of welfare. This means that the growth rate of GDP is accompanied by an equitable distribution of income, equity in development between regions, poverty reduction and the reduction of unemployment can affect people's welfare improvement. This is also supported by empirical facts regarding the improvement of the quality of economic growth with the indicator rate of GDP growth on income distribution as measured by the index gini ratio, equitable development between regions measured by Williamson Index, the poverty rate as measured by the percentage of poor people and the expansion of employment opportunities as measured by the level of unemployment in some districts / cities in Southeast Sulawesi province during the period 2006 to 2015 is likely to decline from year to year.

The results of this study are consistent with the opinion of Sudantoko H. Djoko (2009) which states that the construction carried out a country / region develops focused on efforts to increase economic growth and per capita income in the maximum level, so that the growth will create prosperity trickling down effect (tricke down effect). Also in line with what is proposed by (Sukirno, 2013) which states that the increase in employment, work experience and education will increase production factors, increase the Gross Domestic Product (GDP) or the GDP as the achievement of economic growth in determining the level of prosperity of society and its development. (Sagir, 2009) describes the impact of economic growth on the level of well-being that should be followed by improvement of processes and the quality of welfare development as the final goal (ultimate target) by improving the quality of education, health and welfare are accompanied by an improvement in income distribution and price stability as measured by the use of Human Development Index.

This result is in line with empirical research that has been done by Insukidri (2006) showing the distribution of income by the size of the Gini index in economic growth affect the quality of life index and per capita income. Martin Cooke, et al. (2007) who found that the reduction of the income gap between the community and the unequal distribution of economic development will increase the value of Human Development Index indicator of life expectancy, educational attainment and income level of the community average. Kanayo Ogujiuba (2011) which also expressed the need for policy measures to alleviate poverty, the creation and expansion of employment in order to accelerate a variety of economic interests and economic resources to be utilized as well as possible for all people. Najid Ahmad, et al. (2012), which requires the public to reduce income gaps between 
regions in order to improve the Human Development Index. Keya Chakraborty and Sen (2013) regarding the extent of inequality can be addressed with the development of the fruits of development can improve the Human Development Index. Cristina Balaceanu and Diana Apostol (2014) which explained thatefforts poverty, the gap between regions can reflect on welfare if it can show an increase in per capita income in general. $\mathrm{V}$. Kuznetsova Natalia and Natalia Vorobeva A., (2015), also stressed the GDP growth, reduction of unemployment, income distribution Gini index value for the improvement and poverty reduction positive effect of increasing per capita income and the Human Development Index.

\section{CONCLUSIONS AND RECOMMENDATIONS}

Conclusion; Economic growth quality have significant impact with a positive direction to the level of society welfare in several districts / cities in Southeast Sulawesi. This means that the economic growth quality that proxy with the pace of GDP growth, Gini Ratio Index, Williamson Index, the percentage decline in poverty and unemployment to the level of society welfare in several districts / cities in Southeast Sulawesi which proxy with income per capita and Humans Development Index. This suggests that an increase in economic growth quality during the period from 2006 until 2015, is able to improve the general of society welfare in Southeast Sulawesi. Suggestion; The high economic growth should be directed towards the equitable distribution of income, equity in development between regions, poverty reduction and the expansion of employment in order to raise income per capita of the people and provide the fulfillment of the basic needs of a better form of health, education and life expectancy that is measured by the value of the Humans Development Index tall one.

\section{REFERENCES}

[1]. Agus Widarjono, 2013, Ekonometrika, Pengantar dan Aplikasi Disertai Panduan Eviews, UPP STIM YKPN, Yogyakarta

[2]. Branson H. Willam, James M Litvack, 1981, Macro Economic, Second Edition, Harver International Edition, New York.

[3]. BPS, 2015, Sulawesi Tenggara Dalam Angka.

[4]. Cristina Balaceanu and Diana Apostol, 2014, GDB As a Measurement For The Human Development, Economy Sries, Issue 6 Academica Brancusi Publiser ISSN 2344-3685/ISSN- L 1844-7007, University Of Targu Jiu.

[5]. Hasbullah, Jousairi, 2012, Tangguh Dengan Statistik, Akurat Dalam Membaca Dunia, Nuansa Cendekia, Bandung.

[6]. Insukidri, 2006), Kemiskinan dan Distribusi Pendapatan di Daerah Istimewa Yogyakarta, FEKON UGM (Online),(http://www.Member.fortunecity.com.fekon/ugm.html) diakses pada tanggal 16 Pebruari 2016.

[7]. Kanayo Oquijiuba, Kennety Obi and Enwere Dike, 2011, Poverty, Social Structure, Wealth Distribustion and Market Understanding The Nexus, Economic and Finance Review Vol. 1(6) pp. 01 - Agustus, ISSN: 2047-0401.

[8]. Keya Chakraborty and Joy Sen, 2013, “Utility Assesment of Human Development Indicator Case of Kolkata Urban Agglomeration, Senior Research Schoolar and Associate Professor, Department Of Architecture and Regional Planning, II T Kharagpur, India.

[9]. Kuznetsova, Natalia V. and Natalia A. Vorobeva, 2015, Evaluation Of Economic Development Of India During The Period Of The Global Crisis, Socioeconomica - The Scientific Journal for Theory and Practice of Socio-economic Development Vol. 4 (7): 127144. Izvorni naučni članak, Original Scientific Paper.

[10]. Marinela, Gemanu, 2012, Reference Models Of Endogenous Economic Growth, Jounal Title Anale: Seria Ştiinţe Economice, Timişoara, Vol. XVIII363-368, ISSN 1582-2680 (Print); 1582-6333 (Online), Publisher: Mirton Publishing, Romania.

[11]. McClave James T, Benson P George, Sincich Terry, 2005, Statistics For Business and Economics, Ninth Edition, Pearson Prentice Hall, United States Of America.

[12]. Najid Ahmad, Muhammad Lukman, Muhammad Farhat Hayat, Arslan Ahmadi, Bahauddin Zakariya, 2012, The Impact Of Trade Liberalitation, Population Growth and Income Inequality on Poverty a Case Study Of Pakistan, Research Journal of Economic, Business and ICT, Vol. 5 ISSN 2045, University of the Punjab, Pakistan.

[13]. Mankiw N. Gregory, 2001, Makro Ekonomi, Edisi Kelima, Penerbit Erlangga, Jakarta.

[14]. ............................, 2008, Makro Ekonomi, Edisi Keenam, Penerbit Erlangga, Jakarta.

[15]. Prasetyo Eko, 2008, The Quality Of Growth, Peran Teknologi dan Investasi Human Capital Sebagai Pemicu Pertumbuhan Ekonomi Berkualitas, JEJAK, Volume 1 Nomor 1, Biro Analisa Anggaran dan Pelaksananan APBN, Jakarta.

[16]. Kuznets, Simon, 1955, Economic Growth And Income Inequality, The American Economic Review, Volume XLV March, 1955 Number One.

[17]. Sagir Soeharsono, 2009, Kapita Selekta Ekonomi Indonesia, Edisi I Cetakan I, Penerbit Kencana Prenada Media Group, Jakarta.

[18]. Sjafrizal, 2008. Ekonomi Regional, Teori dan Aplikasi, Padang, Baduose Media.

[19]. Sudantoko H. Joko dan Hamdani Muliawan, 2009, Dasar-dasar Pengantar Ekonomi Pembangunan, Cetakan I, Penerbit PT. PP. Mardi Mulyo, Jakarta Selatan.

[20]. Sukirno, Sadono, Makro Ekonomi, 2013, Teori Pengantar, Edisi Ketiga, Devisi Buku Perguruan Tinggi, PT. Raja Grafindo Persada, Jakarta.

[21]. Todaro, Michael P, 2003, Pembangunan Ekonomi di Dunia Ketiga, Edisi Keenam (terjemahan), Erlangga, Jakarta.

[22]. Undang - Undang Republik Indonesia Nomor 6 Tahun 1974 Tentang Ketentuan-Ketentuan Pokok Kesejahteraan Sosial, diakses melalui www.dpr.go.id/dokjdih/document/uu/UU_1974_6.pdf.

[23]. UNDP, 2004, Human Development Report 2004, New York

[24]. UNDP, 2006, The Quality of Economic Growth and Its Impact on Human Development, The Goverment of The Republic Of Moldova.

[25]. Wold Bank, 2000, The Quality of Growth, Kualitas Pertumbuhan, Penerbit PT. Gramedia Pustaka Utama, Jakarta.

[26]. ..................... 2004, Growth, Inequality and Poverty, Chafter 3 in The Word Development Report 2003/2004: Attacking Poverty, The World Bank, Oxford University Press. 